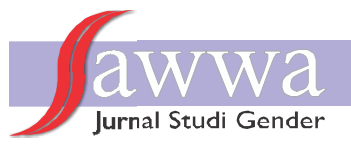

\title{
Reclaiming Identity: Women, Social Exclusion, and Resistance in Bumi Manusia
}

\author{
Muhammad Jauhari Sofi, 1 \\ Nasim Basiri ${ }^{2}$ \\ ${ }^{1}$ Institut Agama Islam Negeri Pekalongan, \\ Pekalongan-Indonesia, ${ }^{2}$ Oregon State \\ University, USA
}

Corresponding Author: Muhammad Jauhari Sofi, email: jauharisofi@gmail.com, Jl. Kusuma Bangsa No.9, Panjang Baru, Pekalongan Utara, Kota Pekalongan, Jawa Tengah 51141

\begin{abstract}
This paper aims to unveil the gender-based prejudice and the colonial state's policies that systematically exclude Native women by considering Pramoedya A. Toer's Bumi Manusia. It focuses on how women are excluded from useful social life participation and resist such unfair treatment to reclaim their own identity. Aclose textual analysiswith postcolonial and feminist discourses was used in this literary study to interpret particular feelings, experiences, and events in the novel. After a comprehensive examination, the study found that women during the Dutch occupation in Java were denied their rights, freedom, and opportunities crucial to their social integration; they had to live their lives according to the interests of the ruling classes, i.e., the men and the white Europeans. Various forms of resistance, ranging from the lowest opposition mode to open rebellions, have been articulated as a response to the said social exclusion. In this sense, the novel exposes a female character that can take on a new form of existence. The insights gained from this study might be of assistance to confirm the awakening of women's consciousness in struggling against the oppressive power of sexism and racism in early twentieth century Java.
\end{abstract}

$\begin{array}{ll}\text { Keywords: } & \begin{array}{l}\text { Bumi Manusia; identity; resistance; social } \\ \text { exclusion; native women }\end{array}\end{array}$

Abstrak: Artikel ini bertujuan mengungkap prejudice berbasis gender dan kebijakan-kebijakan pemerintah kolonial yang secara sistematis mengucilkan wanita pribumi dengan merujuk pada novel Bumi Manusia karya Pramoedya A. Toer. Artikel ini berfokus pada bagaimana wanita dikucilkan dari partisipasi sosial serta bagaimana mereka melawan ketidakadilan tersebut dalam rangka mengklaim kembali identitas mereka. Kajian sastra ini menggunakanclose textual analysisdengan diskursus postkolonialisme dan feminisme guna menafsirkan berbagai perasaan, pengalaman dan peristiwa yang terjadi dalam novel Bumi Manusia. Kajian ini menemukan bahwa wanita pada zaman pendudukan Belanda di Jawa tidak diberi hak, kebebasan dan peluang yang dapat mendukung proses integrasi mereka di masyarakat; sebaliknya, mereka dituntut untuk menjalani hidup menurut kehendak para kelas penguasa, yakni kaum pria dan kaum kulit putih. Berbagai bentuk perlawanan mulai dari penentangan paling minimal hingga pemberontakan terbuka telah dilakukan sebagai respon terhadap upaya pengucilan sosial ini. Dalam hal ini, novel Bumi Manusia menampilkan karakter wanita yang mampu menghadirkan suatu eksistensi jenis baru. Pemahaman yang diperoleh dari kajian ini dapat turut mengkonfirmasi kebangkitan kesadaran kaum wanita dalam me- 
lawan penindasan atas dasar perbedaan kelamin dan ras di Jawa awal abad kedua puluh.

Kata Kunci: Bumi Manusia; identitas; perlawanan; pengucilan sosial; wanita pribumi

\section{A. Introduction}

The social atmosphere at the turn of the twentieth century Java was tense with widespread debate centering on questions about rights and freedom. During the period, Java was oppressed first by the internal power of the local lords and again by the external power of the white colonizers, ${ }^{1}$ in addition to the patriarchal culture, as a result of the Cultivation System policy in the Archipelago. Pramoedya A. Toer's Bumi Manusia is deeply rooted in such a time setting, in which the indigenous people are deliberately kept to remain forever powerless and silent to make the colonial operation much more manageable. The novel, which portrays the dark side of Indonesian life during the colonial period, gives a particular way of looking at the national identity through its main characters.

Through the main characters, Bumi Manusia also raises a complicated relationship between indigenous culture and colonial culture. The relationship is complicated because the former sees the latter as both exploitative and nurturing at the same time. As a result, it creates a new transcultural blend whose mimicry is never far from mockery. Here, the indigenous people use this transcultural blend to challenge colonial authority.2 This psychological ambivalence corresponds to the so-called Ethical Policy issued in 1901, with which the colonial government tried to raise awareness among the Natives of the need to free themselves from the chains of the feudal system and to develop themselves with reference to the European or Western lines. ${ }^{3}$

Recent evidence suggests that Bumi Manusia has been observed from various angles. Using the Marxism approach, the novel is once associated with the class struggle to eradicate the injustice perpetrated by the Europeans representing the bourgeoisie, ${ }^{4}$ while it is also linked to a fight against patriarchal

1 Sanne Ravensbergen, “Courtrooms of Conflict: Criminal Law, Local Elites, and Legal Pluralities in Colonial Java (Ph.D. Dissertation)” (Universiteit Leiden, 2018).

2 Homi K. Bhabha, The Location of Culture (London: Routledge, 1994), 121.

${ }^{3}$ R.M.A. van der Schaar, "Colonial Period of Indonesia," Indonesia-Investments, n.d., https://www.indonesia-investments.com/culture/politics/colonial-history/item178.

${ }^{4}$ Risnawati Risnawati, Anshari Anshari, dan Aslan Abidin, "Pertentangan dan Kesadaran Kelas dalam Novel Bumi Manusia Karya Pramoedya Ananta Toer: Pendekatan Teori Marxis,” Retorika 9, no. 1 (2016): 68-79, https://doi.org/10.26858/retorika.v9i1.3795. 
power in traditional Java. ${ }^{5}$ Such expositions, nevertheless, are unsatisfactory because they look at issues in the novel separately. Other studies examine the novel with semiotics ${ }^{6}$ and the stylistic approach, claiming that certain dictions in the novel should indicate the author's admiration for European civilization. ${ }^{7}$ Meanwhile, a sociological perspective maintains that the novel's stories present a general picture of the relationship between East Java and the Europeans in the early twentieth century. Though such approaches are interesting to notice, they do not have much to do with the novel's main idea.

This study is of interest because it sets out to investigate the novel's issues more comprehensively. It examines women's position as the subaltern class in both patriarchal and colonial systems and how they try to articulate their voices to be heard by the ruling classes, i.e., the men and the white Europeans. Thus, it will generate fresh insight into feminist studies in Indonesia. Aclose textual analysis with postcolonial and feminist discourses was used in this literary study to interpret particular feelings, experiences, and events in the novel. The significant advantage of these two discourses is that they can portray double colonization on women: the entwined sexism and racism.

\section{B. Postcolonial and Feminist Concerns}

The popular understanding of the term postcolonial is that it refers to the period that comes after colonialism. Though that idea is difficult to maintain any simple tendency, the term is sufficient to confirm that postcolonialism must have its root in colonialism's historical context. As history records, violence is the very nature of colonialism. Colonial violence is generally linked to situations, processes, and any relationships that deal with colonialism and lead to social, physical, and psychological violence of the subaltern colonial subjects. It is a fundamental part of the Third World nations' history that no literature or

\footnotetext{
${ }^{5}$ Ahsani Taqwiem, “Perempuan dalam Novel Bumi Manusia Karya Pramoedya Ananta Toer," Jurnal Tarbiyah 7, no. 2 (2018): 133-43, https://doi.org/10.18592/tarbiyah.v7i2.2217.

${ }^{6}$ Embang Logita, "Kajian Strukturalisme Semiotik dalam Novel Bumi Manusia Karya Pramoedya Ananta Toer," Bahtera Indonesia: Jurnal Penelitian Bahasa dan Sastra Indonesia 2, no. 2 (1 September 2017): 41-51, https://doi.org/10.31943/bi.v2i2.34.

${ }^{7}$ Ardik Ardianto, "Gaya Kepenulisan Pramoedya: Stilistika atas Roman Bumi Manusia," Kembara: Journal of Scientific Language Literature and Teaching 6, no. 1 (7 Mei 2020): 39-48, https://doi.org/10.22219/kembara.v6i1.11688.

${ }^{8}$ Nur Hastuti, "Novel Bumi Manusia Karya Pramoedya Ananta Toer, Kajian Sosiologi Sastra," Humanika 25, no. 1 (2018): 64-74, https://doi.org/10.14710/humanika.v25i1.18128.
} 
critical approach has ignored. ${ }^{9}$ Colonialism, therefore, provides a backdrop to the postcolonial discourse.

As quoted by Peter Childs and Patrick Williams, Bill Ashcroft locates the term postcolonial not as periodization, rather the impact of colonialism on different aspects since the beginning of colonization. He maintains:

"We use the term postcolonial to cover all the culture affected by the imperial process from the moment of colonization to the present day. This is because there is a continuity of preoccupations throughout the historical process initiated by European imperial aggression." 10

From that point, we know that postcolonial study like the one seen in Bumi Manusia reexamines political and cultural resistance to colonialism history and possibly reveals a neocolonial system at present. It is a critique meant to evoke fresh ideas, such as emancipation, equality, and social justice for the colonized subjects, to counter the systematic structure of oppression and exclusion based on race. The postcolonial study is a disciplinary enterprise carefully designed for "the academic task of revisiting, remembering, and interrogating the colonial past" that has been silenced or erased by both colonial and nationalist powers. ${ }^{11}$ Discussion in this literary study may include the absurdity of the colonizer's so-called civilizing mission (ambivalence), the human dichotomy between the selfand the other (alterity), and the fight against exclusion (resistance).

Like the colonized subjects, women in patriarchal culture have been alienated as the other, the excluded, and the oppressed. They are both subordinated in society and, thus, powerless. During the Dutch occupation in Java, women's position could become even worse if they come from the lower class. Given this position, women might suffer double and triple colonization under racism, sexism, and classism. Within this framework, feminist concerns in Bumi Manusia try to readjust the excluded women in the face of the ruling classes; they seek to invert the structure of domination in colonial Java through individual experiences and struggles of a Native woman. Later, discussion on this issue may involve different perspectives of feminism, e.g., radical feminism, Marxist feminism, and liberal feminism..$^{12}$

\footnotetext{
${ }_{9}^{9}$ Pramod K. Nayar, Postcolonial Literature: An Introduction (Delhi: Pearson, 2008), 15-16.

${ }^{10}$ Peter Childs dan Patrick Williams, An Introduction to Post-colonial Theory (London: Prentice Hall/Harvester Wheatsheaf, 1997), 3.

${ }^{11}$ Nayar, Postcolonial Literature: An Introduction, 17-18.

${ }^{12}$ Sylvia Walby, Theorizing Patriarchy (Oxford, UK \& Cambridge, USA: Blackwell Publisher Ltd., 1990), 3-4.
} 
Bumi Manusia is the first out of the four books that comprise Pramoedya A. Toer's renowned Buru Quartet. As the Indonesians popularly call the author, Pram has originally composed it as an oral narrative to his fellow prisoners in 1973 while in Buru Island's Prison. Typed in 1975 when he was finally allowed to write, the novel depicts the Dutch colonial life between 1898 and 1918,13 i.e., a period that also marks a new approach within the Dutch Indies called the Ethical Policy, and that paves the way for the awakening of Indonesian nationalism. This Ethical Policy provides small Indonesian elites with modern organizations and Western political ideals of freedom and democracy. ${ }^{14}$

The novel's manuscript was initially sent to Hasta Mitra, publisher by an ex-political prisoner and former editor of a newspaper, and was successfully published on August 25, 1980. Within a few months after its first publication, several publishers in Hong Kong, Malaysia, the Netherlands, and Australia approached Hasta Mitra to prepare translations. A year later, the book has been printed as many as ten times. However, in 1981 the Attorney General of Indonesia banned the book because it was claimed to promote Marxist-Leninist doctrines and Communism. In the same year, the English version of the book was available, i.e., This Earth of Mankind, and then produced in Australia by Penguin Books Australia a year later. ${ }^{15}$

Unlike Toer's feminist works displaying feudal life in Java, e.g., Gadis Pantai, ${ }^{16}$ Bumi Manusia focuses on colonial life. On the one hand, it highlights a paradoxical aspect of colonialism and imperialism. The Dutch colonial government in Indonesia was driven by contradictions between educating the Native people and exploiting them. Its female protagonist named Sanikem or Nyai Ontosoroh, for example, gets the benefit of the mind-liberating books and knowledge initiated by her European husband. However, this education ultimately makes her aware of the atrocities of the colonizer in her land. Later,

\footnotetext{
${ }^{13}$ Keith Foulcher, “'Bumi Manusia' and 'Anak Semua Bangsa': Pramoedya Ananta Toer Enters the 1980s," Indonesia 32 (1981): 1-15, https://doi.org/10.2307/3350853.

${ }^{14}$ Ravensbergen, "Courtrooms of Conflict: Criminal Law, Local Elites, and Legal Pluralities in Colonial Java (Ph.D. Dissertation)," 383; Schaar, "Colonial Period of Indonesia." 5.

15Pramoedya A. Toer, This Earth of Mankind (transl. by Max Lane) (New York: Penguin, 1990),

${ }^{16}$ Muhammad Jauhari Sofi, "Politics of Female Identity in Traditional Java through the Prism of Pramoedya A. Toer's Gadis Pantai," Jurnal Walisongo 26, no. 2 (2018): 345-64, https://doi.org/http://dx.doi.org/10.21580/ws.26.2.3181.
} 
this ambivalent relationship between the Natives and the white colonizers brings a complex mixture of attraction and repulsion. ${ }^{17}$

On the other hand, Bumi Manusia importantly depicts women living in a colonial and patriarchal society through its female protagonist's life. The novel addresses narratives that exclude women from useful participation in social life during the Dutch colonial state at the turn of the twentieth century Java. It portrays how Native women have been exploited and alienated to the position of "the other", a term intended to instill the significance of the ruling class and the insignificance of the excluded class. ${ }^{18}$ As people mostly believe, the novel has been propelled by Raden Ajeng Kartini (1879-1904), the Indonesian priyayi's girl renowned for her book of letters written in Dutch. For a long time, her three-fold fight for the re-evaluation of Javanese culture, the equal opportunity of education for women, and monogamy promotion had been the general goals for feminism in the country. 19

The author of the novel eloquently explores the primary female character who has a rebellious spirit and desires for a change within her society where women, in general, wish to be treated justly. His female character speaks out to the needs of both collective and individual female identity within their culture during the Dutch occupation in Java, Indonesia. The author shows that the best way one might face social exclusion is to refuse it in any possible way and reclaim their dignity rather than be submissive and let it pass unchecked. He employs a female hero who shouts out a universal aspiration for all humankind's equity, regardless of their sexual and racial differences.

\section{Narratives on Social Exclusion in Colonial Java}

In colonial Java, fate as the daughter of a man never satisfied with his position could bring a painful impact on the daughter. To become the most respectable man among people in the community, a father might think of a daughter or even a wife's circulation as property. In Bumi Manusia, clerk Sastrotomo sold his daughter named Sanikem (Nyai Ontosoroh) to Tuan Besar

\footnotetext{
17Eiman O. Elabdin, Postcolonialism Meets Economics (London: Routledge, 2004), 238.

${ }^{18}$ John C. Hawley, Encyclopedia of Postcolonial Studies (Westport, Connecticut: Greenwood, 2001), 17.

${ }^{19}$ Elsbeth Locher-Scholten, Women and the Colonial State: Essays on Gender and Modernity in the Netherlands Indies 1900-1942 (Amsterdam: Amsterdam University Press, 2000), 21, https://doi.org/10.5117/9789053564035.
} 
Kuasa, owner of a sugar factory, in a barter position as a cashier. Sastrotomo rooted a patriarchal culture where a father symbolically assumed power over women by locating them as an exchanged object. ${ }^{20}$

Sanikem narrated how the transaction took place:

"Tuan Besar Kuasa took out an envelope from his pocket and handed it to Father. He also took out a piece of paper writing on it, and Father put his signature. Afterward, I found out the envelope contained twenty-five guilders, representing Father's surrender of me to him, along with the promise that Father would be made cashier after first completing a two-year trial period."21

Sold by her father, the 14-year-old girl could only submit to her fate. Rights to utter her desires concerning the choice of a spouse were impoverished. She became the victim of her father's ambition to pursue status, position, and power. ${ }^{22}$

To illustrate, the concubinage practice through a forced marriage as faced by Sanikem was quite common for young Javanese girls during the colonial time. At the moment, the girls could only surrender and wait for a man to take them from home to a place they did not know. The girls did not know anything about this man with whom they were going to spend their life; they had no idea whether he was young, old, criminal, drunkard, or gambler. Their father determined everything for them. Once married, they had to perform duties and services for this man. This went on until they passed away, or the man got bored and then removed them. They did not choose but to follow the patriarchal system giving unreasonable power to the father, the men.

Indeed, in a patriarchal society of colonial Java, a father's position became critical in the family to the extent that it also granted him a particular position in society. The father that represented capitalist patriarchy determined everything concerning the needs of the family. ${ }^{23}$ This notion made men leaders who had to be respected and obeyed by all family members and society, especially women. Men held authority over women, which gradually resulted in the idea

\footnotetext{
20Veronica Beechey, “On Patriarchy," Feminist Review 3 (1978): 66-82, https://doi.org/https://doi.org/10.1057/fr.1979.21.

${ }^{21}$ Toer, This Earth of Mankind (transl. by Max Lane), 84.

${ }^{22}$ Martha E. Gimenez, "Capitalism and the Oppression of Women: Marx Revisited," Science \& Society 69, no. 1 (2005): 11-32, https://doi.org/10.1521/siso.69.1.11.56797.

${ }^{23}$ Zillah R. Eisenstein, Capitalist Patriarchy and the Case for Socialist Feminism (New York: Monthly Review, 1979), 17.
} 
that women were part of men's property. Consequently, the men could easily and freely negate the voice and rights of the women. The practice of usurping women's rights during the Dutch colonial power coincided with Spivak's view $^{24}$ that saw women as the subaltern. Being the subaltern, women's voices were always silenced because of the power vested in men's hands.

Next, women in traditional Javanese society were generally confined to the domestic sphere. They were denied access to certain rights that were possible for men. For example, when Sanikem was about to reach the age of consent in the novel, her parents kept her at home. Since then, her world was limited only to her room, back parlor, and, of course, kitchen. Unless a relative or neighbor, but not a foreigner, visited her family, she would probably never feel the freedom to meet people as she ever had in her childhood. Indeed, a girl in her age was neither permitted to sit on the porch nor reach its floor. ${ }^{25}$ The parents were very protective that the daughter could not interact with the world outside the home. They restricted her to interact only with women. This sexual division, which manifested in the woman's role as a mere domestic laborer, housekeeper, and mother within the family, was deliberately preserved via marriage and the family. ${ }^{26}$

Javanese patriarchal society set out to prepare women to be good wives, mothers, and daughters and discourage them from engaging social roles in the arena outside their home. The parents did not even send them to school, except those coming from an aristocratic family. ${ }^{27}$ Here, the colonial policies allowed women of the Indonesian upper-class society to access education but insisted those of the lower-class society remain underdeveloped in their ancient, uncivilized world as possible as they could. ${ }^{28}$ Women were perceived as responsible mainly for kitchen tasks and were not allowed to do outdoor-type

\footnotetext{
${ }^{24}$ Jay Maggio, “'Can the Subaltern Be Heard?': Political Theory, Translation, Representation, and Gayatri Chakravorty Spivak," Alternatives: Global, Local, Political 32, no. 4 (21 Oktober 2007): 41943, https://doi.org/10.1177/030437540703200403.

${ }^{25}$ Toer, This Earth of Mankind (transl. by Max Lane), 81.

26Eisenstein, Capitalist Patriarchy and the Case for Socialist Feminism, 18.

${ }^{27} J$ Jean Gelman Taylor, "Kartini in her historical context," Journal of the Humanities and Social Sciences of Southeast Asia 145, no. 2 (1989): 295-307, https://doi.org/10.1163/2213437990003256

${ }^{28}$ Locher-Scholten, Women and the Colonial State: Essays on Gender and Modernity in the Netherlands Indies 1900-1942, 28.
} 
activities, especially mingling with men in the workplace. ${ }^{29}$ They should also not even think about honor and self-respect. ${ }^{30}$

Other necessary forms of women's exclusion are seen when Sanikem was finally made a nyai or concubine of a Dutchman named Herman Mellema. By the locals, she was now known as Nyai Buitenzorg or Nyai Ontosoroh, a name associated with Mellema's dairy business, i.e., Boerderij Buitenzorg. As a nyai, not only was Nyai Ontosoroh responsible for the domestic sphere, but also she should be able to act as a mistress to her master, the husband. ${ }^{31}$ Therefore, she then tried to learn the Europeans' language and culture and became proficient in them. However, her relationship with Herman Mellema was an illegal bond in the European law's eyes, and, hence, her children were considered illegitimate.

During the colonial time in Java, many Dutch officials kept a Native girl used as a concubine or nyai. The children of a relationship between a nyai and her master were called Indo, a Dutch-Native mixed marriage child. Referring to the new Mix Marriage Regulation issued in 1898, only the father would possess the right to give European citizenship to his Indo children; ${ }^{32}$ the mother would never be granted guardianship's rights to her children even after the father died. In such a case, the children's legal status would then be submitted to the European Court of Justice. Later, if the court did not legally acknowledge the children, they could be heartlessly discarded along with their Native mother. ${ }^{33}$

Narrated in the novel, the success of Boerderij Buitenzorg as a big commercial business has attracted Engineer Maurits Mellema, the legitimate son of Herman Mellema from his European wife in the Netherlands, to come and see its owner. Nyai Ontosoroh informed that before Mr. Mellema's death, Maurits once ever visited her house. In loud Malay, he spoke abusively and egoistically to Nyai in a manner that, according to her, was impolite and contrary to the noble values of European culture. ${ }^{34}$ As a talk between the father

${ }^{29}$ Toer, This Earth of Mankind (transl. by Max Lane), 133.

${ }^{30}$ Toer, 89.

${ }^{31}$ Reggie Baay, Nyai dan Pergundikan di Hindia Belanda (Jakarta: Komunitas Bambu, 2010), 1.

${ }^{32}$ Razif Bahari, "Between a Rock and a Hard Place? Interstitial Female Subjectivity in between Colonialism and Patriarchy: Women in Pramoedya Ananta Toer's Buru Tetralogy," Indonesia 83 (2007): 41-77.

${ }^{33}$ Bahari.

34Toer, This Earth of Mankind (transl. by Max Lane), 96. 
and the son progressed, whereas Nyai was there listening to it, she became a victim of Maurits' verbal abuse by othering her from the white European culture. ${ }^{35}$ Maurits accused Nyai as a mere bedmate, and her marriage with his father is an unforgivable sin.

Following Mr. Mellema's death, the Dutch law puts Nyai Ontosoroh as a suspect responsible for the said case. First, his death indicated Nyai's inability to take care of her master, her husband. In the colonial law, though a nyai and the master had a close relationship, it was no more than a relationship between the master and the slave who had to serve and take care of her or his master. According to European perception, Nyai Ontosoroh was the ultimate otherdifferent in race, class, and religion, so that her rights were automatically cut off. Equally important, Nyai, along with Minke, was also accused of plotting the murder of Mr. Mellema with financial motives to suck on his entire wealth. ${ }^{36}$

Mr. Mellema's death also drove son Maurits to come to the Dutch East Indies for the second time. At the moment, his mission was to expropriate the late Mellema's entire property from Nyai and the guardianship of Indo Annelis. Maurits understood that the European law would not hand over Mellema's wealth to a Native concubine. This notion comes true when Nyai Ontosoroh finally received several official documents from the Amsterdam District Court that gave power to an attorney to arrange any possible efforts to seize the rights of the legacy left by the late Herman Mellema and authorizes the Surabaya District Court to execute the case. ${ }^{37}$ In this scene, we can see that the dispute concerning the rights of inheritance and guardianship over Indo-children can reflect the operation of the discriminating colonial law, as it only secures the rights of those with European citizenship at the cost of the Natives.

The colonial law greedily usurped the Native woman's rights as a business partner and as a mother. The white Europeans tried to rob the fruits of Nyai's hard work and all that she has been struggling to obtain over the past two decades. She also lost all rights to her children. The Dutch European law only recognized them as Mr. Mellema's children and not as the lawful children of

\footnotetext{
${ }^{35}$ Bill Ashcroft, Gareth Griffiths, dan Helen Tiffin, Key Concepts in Post-colonial Studies (London: Routledge, 1998), 12.

36Toer, This Earth of Mankind (transl. by Max Lane), 278.

37Toer, 325-26.
} 
Nyai Ontosoroh. ${ }^{38}$ This situation shows that Native women were excluded in colonial times. Their rights were neglected, and their voices were not accommodated. In this sense, again, the European court's decision unmasked the white colonizers' real attitude, who always exploited women's weak status.

Besides, the language used during the trial process is also a big concern. In the court, Nyai Ontosoroh was denied permission to speak Dutch, the court's official language, though she could do so. Commanded to use Javanese, she refused. Nyai was asked to speak in Malay instead. This situation benefited the Dutch colonizers because she could not freely voice her rights to the Dutch listeners if she used the Malay language. Therefore, other people would do the translation on behalf of her. This situation is in line with Spivak's opinion that the subaltern woman is never allowed to directly voice her problems. ${ }^{39}$ Here, Nyai was systematically excluded in terms of the opportunity to use the language of the court.

\section{Profound Rebirth and a New Form of Existence}

In the novel, Sanikem looked submissive in response to the father selling her to Herman Mellema to be his mistress. Her father was sold into concubinage to ingratiate himself with his Dutch masters and advance his position. ${ }^{40}$ However, her submissiveness did not mean that she did not resist the social inclusion addressed to her. Instead, Sanikem was too inferior to undertake the open resistance at the moment. She was not only facing her father but also the patriarchal culture fossilizing in the Javanese society. Sanikem did resist such unfair treatment but in a very passive way. 41

Given the inferior position, Sanikem was in a state of despair as if even her tears and objection did not help much in changing the father's decision. Here, crying and refusing to look at the father's face could be interpreted as a form of an internalized exile that brought her to a liminal state of consciousness to resist domination. By crying, she attempted to reconnect her resistance with her body

\footnotetext{
${ }^{38}$ Locher-Scholten, Women and the Colonial State: Essays on Gender and Modernity in the Netherlands Indies 1900-1942, 31.

${ }^{39}$ Maggio, “'Can the Subaltern Be Heard?': Political Theory, Translation, Representation, and Gayatri Chakravorty Spivak" 1980s."

${ }^{40}$ Foulcher, 'Bumi Manusia' and 'Anak Semua Bangsa': Pramoedya Ananta Toer Enters the

41Toer, This Earth of Mankind (transl. by Max Lane), 76.
} 
and community. ${ }^{42}$ Sanikem lost her hope to determine her own life. She found herself unable to do any other thing, except to accept the fact that she would become a nyai through forced marriage. This powerlessness creates what socalled a culture of silence was. Sanikem became so powerless that she did not even talk about her systematic oppression. ${ }^{43}$ She realized that the father would just ignore anything she said in her defense. She knew that her protest would never help.

Later, within a year, Sanikem (from now on called Nyai Ontosoroh or simply Nyai) lived with Mr. Mellema, her parents came to visit her several times, yet she refused to accept them. According to Ketu H. Katrak, this unwillingness to meet them could be identified as one form of resistance from relatively unthreatening ones. ${ }^{44}$ In traditional Java, children were obliged to show honor and politeness to the elders, especially the parents, ${ }^{45}$ yet Nyai did not. Here, she implicitly declared to Mr. Mellema that she no longer had either a father or mother. She refused to acknowledge Sastrotomo and his wife as her father and mother because they did not have the quality to be parents. Nyai was not able to forgive the father's selfish ambition for wealth and status and the helplessness of the mother.

However, during the new life with Mr. Mellema, Nyai Ontosoroh transformed into a new woman with an utterly remarkable personality. She has left her past identity as a weak woman and has become an independent and intelligent woman. In her new identity, she was a powerful woman who saw the world as one of profit and loss. This transformation signified her refusal of the men's monopoly of power. Nyai could now determine her fate without the interference of her parents, especially the father. She also insisted that her children be educated and self-dependent to not experience the Sanikem's fate. Nyai resisted against the practice of traditional Javanese parents who left their children in backwardness, especially the women. At this point, she adopted the

\footnotetext{
${ }^{42}$ Ketu H. Katrak, Politics of the Female Body: Postcolonial Women Writers of the Third World (New Brunswick, New Jersey: Rutgers UP, 2006), 2.

43Paulo Freire, The Politics of Education: Culture, Power and Liberation (South Hadley, Massachusetts: Bergin \& Garvey, 1985), 28.

${ }^{44}$ Katrak, Politics of the Female Body: Postcolonial Women Writers of the Third World, 62.

${ }^{45}$ Hildred Geertz, Keluarga Jawa (Jakarta: Grafiti Pers, 1983), 59.
} 
European perception that it was economic factors rather than traditions that finally determined women's presence. ${ }^{46}$

Later, the coming of Mellema's biological son named Maurits to the Mellema Family in Surabaya clearly illustrates how Nyai struggled against racial discrimination. Maurits repeatedly humiliated Nyai in front of Mr. Mellemas's eyes, while Mr. Mellema himself did nothing to defend his wife. Maurits charged Nyai with a bedmate and unbeliever, and her children with bastard children. Maurits' attitude corresponded to Edward Said's idea of the binary opposition between colonizer and colonized, positing the latter as the barbaric and ignorant.47 Unbearable with his affront, Nyai felt offended and repelled him from her home. She responded to this exclusion with defiance and strength. The following satirical tone is interesting to notice:

"So, this is the child you had with your legal wife (?), I shouted at Tuan. So this is the European civilization about which you have been teaching me all these years? Have you been glorifying to the heavens? Day and night? Checking into people's private lives and homes, insulting them, to come and blackmail them? Blackmail? What else if not to blackmail?"48

At this point, Nyai challenged Gramsci's notion of hegemony that privileged the colonial culture as a parent, a role model for his colonized child. ${ }^{49}$ Instead of acting like a father who showed good values to his children, European civilization exhibited barbaric practices toward its colony. Since that moment, Nyai has tried to get rid of Mr. Mellema's shadows. First, Nyai ordered the family guard named Darsam to remove all his photos from the walls and burned them in front of the house in front of all people working for her. ${ }^{50}$ Burning properties, referring to Katrak, is a way she probably did to show a refusal to accept him in her life. ${ }^{51}$

However, after Mellema's sense of ethical security was rocked with his European son's presence, the hierarchic power structure reflected through the symbolic relationship between owner and property, master and slave, man and

\footnotetext{
${ }^{46}$ Locher-Scholten, Women and the Colonial State: Essays on Gender and Modernity in the Netherlands Indies 1900-1942, 70.

${ }^{47}$ Edward W. Said, Orientalism (New Delhi: Penguin, 1995), 87.

48Toer, This Earth of Mankind (transl. by Max Lane), 99.

${ }^{49}$ Ashcroft, Griffiths, dan Tiffin, Key Concepts in Post-colonial Studies, 106.

${ }^{50}$ Toer, This Earth of Mankind (transl. by Max Lane), 103.

${ }^{51}$ Katrak, Politics of the Female Body: Postcolonial Women Writers of the Third World, 62.
} 
woman, colonizer and colonized, etc. began to change in a more obvious way. ${ }^{52}$ Equipped with the skills and knowledge she received from her European master, Nyai tried to take hold of the strength that the master once had over her. This way, she exercised the "colonial mimicry as a mode of appropriation and resistance."53 With the same knowledge and skills, she also gradually controlled Mr. Mellema's dairy business and agricultural farm, the Boerderij Buitenzorg, and turned to rule his household. ${ }^{54}$

The reclaiming of the Boerderij Buitenzorg suggests that Nyai Ontosoroh has been able to break the lines of the colonial genealogy and indirectly disrupted the patriarchal arrange that systematically dictated the Dutch East Indies colony. ${ }^{55}$ Nyai, on behalf of the Natives, not only questioned and shook the domination of Colonial power and refused to follow the mainstream of Javanese traditions that tended to be submissive and chose to trouble the Colonial arbitrariness instead. Nyai got up and presented herself as a remarkable Native woman. She challenged the androcentric economy as she broke the boundaries preserved by the patriarchal society in Colonial times.

Likewise, dealing with the scandalous rumor between Nyai and Minke after Mr. Mellema's death, Nyai clearly and confidently responded to the uncivilized insinuating questions of the prosecutor and judge. During the trial, her replay has made the invisible operation, by which the colonial policies embodied exploitative ideologies, become visible and helped dramatize it. At the moment, the court exposed various issues that could not be cleared up, including the unnatural familial relation between the late Herman Mellema and his Native mistress and the improper relation between her guest (Minke) and her daughter (Annelis). Instead of focusing on seeking the truth, the issue of the trial shifted to mockery due to racial differences.

The peak of Nyai's resistance was concerned with the fate of Annelis concerning the rulings of the Amsterdam District Court. Annelis marriage with Minke was also declared not legal since she was considered underage by the

\footnotetext{
52Bahari, "Between a Rock and a Hard Place? Interstitial Female Subjectivity in between Colonialism and Patriarchy: Women in Pramoedya Ananta Toer's Buru Tetralogy."

${ }^{53}$ Bhabha, The Location of Culture, 120.

${ }^{54}$ Bahari, "Between a Rock and a Hard Place? Interstitial Female Subjectivity in between Colonialism and Patriarchy: Women in Pramoedya Ananta Toer's Buru Tetralogy."

${ }^{55}$ Bahari.
} 
court. Nyai insisted on fighting against the colonial court, though, at that time, she had no idea of how to fight. ${ }^{56}$ She did understand that the court would defeat her, yet she demanded to defend her rights. She tried any possible way to fight. Once, she used to hire an attorney to handle her case. However, as Nyai thought that her attorney was too pessimistic about the case's prospect, she fired him.

Further, Nyai was also depressed with the weakness of her people in defending their rights. The following scene depicts Nyai's regret at the unwillingness and inability of her countrymen to fight against colonialism:

"We need not be ashamed if we are defeated. We must know why. Look, Child, Nyo, we all the Natives are unable to hire attorneys. Even if we have money, it does not mean we can do so. The main reason is that we do not have the courage. Furthermore, more generally still, we have not learned anything. All their lives, the Natives, have suffered what we are not suffering. No one raises their voices - dumb like the river stones and mountains, even if cut up and made into no matter what." 57

The above line shows that Nyai finally began to look at her family problem's roots and disregard her personal feelings. She was now putting her problem in the broader context, i.e., the problem of the Natives. While lamenting her people's inability to defend their rights, she bitterly likened them to those with mouths but no voices.

Equally important, Nyai protested the Amsterdam court's decision, which has nullified the marital status of her daughter with Minke.58 Annelis marriage with Minke was nullified; hence, she was legally considered unmarried. However, Nyai asserted that to invalidate it could mean to discredit Islamic law because the marriage has been conforming to Islamic law. In the court, Nyai blatantly hinted at Maurits' intention towards the case; she believed that he intentionally desired to destroy her family, the Natives, as a punishment inflicted for being his father's illegal wife. Here, the author of the novel used the character, Maurits, as a symbolic figure to represent the white Europeans who always viewed the Natives with hatred and used conflict over the business and guardianship as a medium to illustrate the colonial state's policies that protected the rights of white European at the expense of the Native people.

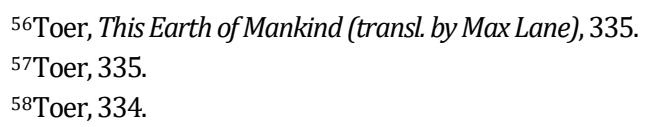


The end of the novel shows the defeat of subaltern women against an established system that excluded them. His female protagonist, Nyai Ontosoroh, was a subaltern woman defeated by the patriarchal and colonial power. However, she still could fight with dignity and courage. It also becomes clear that although education and consciousness have a crucial role in challenging the exercise of the hegemony of the colonial power, the two are, in fact, not enough. Things like morality and law remain decisive. ${ }^{59}$ Annelis ' fragility in dealing with her legal case also indicates the inability and impossibility to build mutual respect and understanding between the Natives and the white colonizers.

\section{E. Conclusion}

This paper sets out to reveal the gender-based prejudice and the colonial state's policies that systematically exclude Native women by considering Pramoedya A. Toer's Bumi Manusia. Examination of the novel has found that women in Java's past have been denied their rights, freedom, and opportunities crucial to their social integration. The patriarchal power mostly confined them to the domestic sphere. Many of them even underwent a forced marriage, placing them as no more than an exchanged property. Women were also victims of multiform racial discrimination, i.e., from verbal abuse in everyday life to constant exclusion before the European law. The excluded women had to live their lives according to the ruling classes' interests, i.e., the male and the white European. This study also found that various forms of resistance, ranging from the lowest mode of opposition to open rebellions, have been articulated according to the said systematic social exclusion. Here, the feminist consciousness reflected through rebellious spirit, confidence, self-reliance, and determination is used to reclaim female identity.

Overall, this study strengthens the idea that such a rebellious spirit marks the awakening of women's consciousness in struggling against the oppressive power of sexism and racism in the early twentieth century Java. It is unfortunate that this study does not include the feudal settings or classism, so that diverse complexity of women's exclusion cannot be fully represented. Therefore, a comparative study of other Toer's works that discusses issues of both colonialism and feudalism, in addition to patriarchal culture, in one academic paper will be interesting to do in the future in order to create a better 1980s."

${ }^{59}$ Foulcher, "Bumi Manusia' and 'Anak Semua Bangsa': Pramoedya Ananta Toer Enters the 
degree of accuracy in describing women's life during the Dutch occupation in Java.[s]

\section{References}

Ardianto, Ardik. "Gaya Kepenulisan Pramoedya: Stilistika atas Roman Bumi Manusia." Kembara: Journal of Scientific Language Literature and Teaching 6, no. 1 (7 Mei 2020): 39-48. https://doi.org/10.22219/kembara.v6i1.11688.

Ashcroft, Bill, Gareth Griffiths, dan Helen Tiffin. Key Concepts in Post-colonial Studies. London: Routledge, 1998.

Baay, Reggie. Nyai dan Pergundikan di Hindia Belanda. Jakarta: Komunitas Bambu, 2010.

Bahari, Razif. "Between a Rock and a Hard Place? Interstitial Female Subjectivity in between Colonialism and Patriarchy: Women in Pramoedya Ananta Toer's Buru Tetralogy." Indonesia 83 (2007): 41-77.

Beechey, Veronica. “On Patriarchy.” Feminist Review 3 (1978): 66-82. https://doi.org/ 10.1057/fr.1979.21.

Bhabha, Homi K. The Location of Culture. London: Routledge, 1994.

Childs, Peter, dan Patrick Williams. An Introduction to Post-colonial Theory. London: Prentice Hall/Harvester Wheatsheaf, 1997.

Eisenstein, Zillah R. Capitalist Patriarchy and the Case for Socialist Feminism. New York: Monthly Review, 1979.

Elabdin, Eiman O. Postcolonialism Meets Economics. London: Routledge, 2004.

Foulcher, Keith. 'Bumi Manusia' and 'Anak Semua Bangsa': Pramoedya Ananta Toer Enters the 1980s." Indonesia 32 (1981): 1-15. https://doi.org/10.2307/ 3350853.

Freire, Paulo. The Politics of Education: Culture, Power and Liberation. South Hadley, Massachusetts: Bergin \& Garvey, 1985.

Geertz, Hildred. Keluarga Jawa. Jakarta: Grafiti Pers, 1983.

Gimenez, Martha E. "Capitalism and the Oppression of Women: Marx Revisited." Science \& Society 69, no. 1 (2005): 11-32. https://doi.org/10.1521/ siso.69.1.11.56797.

Hastuti, Nur. "Novel Bumi Manusia Karya Pramoedya Ananta Toer, Kajian Sosiologi Sastra." Humanika 25, no. 1 (2018): 64-74. https://doi.org/10.14710/ humanika.v25i1.18128. 
Hawley, John C. Encyclopedia of Postcolonial Studies. Westport, Connecticut: Greenwood, 2001.

Katrak, Ketu H. Politics of the Female Body: Postcolonial Women Writers of the Third World. New Brunswick, New Jersey: Rutgers UP, 2006.

Locher-Scholten, Elsbeth. Women and the Colonial State: Essays on Gender and Modernity in the Netherlands Indies 1900-1942. Amsterdam: Amsterdam University Press, 2000. https://doi.org/10.5117/9789053564035.

Logita, Embang. "Kajian Strukturalisme Semiotik dalam Novel Bumi Manusia Karya Pramoedya Ananta Toer." Bahtera Indonesia: Jurnal Penelitian Bahasa dan Sastra Indonesia 2, no. 2 (1 September 2017): 41-51. https://doi.org/10.31943/ bi.v2i2.34.

Maggio, Jay. '“Can the Subaltern Be Heard?': Political Theory, Translation, Representation, and Gayatri Chakravorty Spivak." Alternatives: Global, Local, Political 32, no. 4 (21 Oktober 2007): 419-43. https://doi.org/ 10.1177/030437540703200403.

Nayar, Pramod K. Postcolonial Literature: An Introduction. Delhi: Pearson, 2008.

Ravensbergen, Sanne. "Courtrooms of Conflict: Criminal Law, Local Elites, and Legal Pluralities in Colonial Java (Ph.D. Dissertation)." Universiteit Leiden, 2018.

Risnawati, Risnawati, Anshari Anshari, dan Aslan Abidin. "Pertentangan dan Kesadaran Kelas dalam Novel Bumi Manusia Karya Pramoedya Ananta Toer: Pendekatan Teori Marxis." Retorika 9, no. 1 (2016): 68-79. https://doi.org/ 10.26858/retorika.v9i1.3795.

Said, Edward W. Orientalism. New Delhi: Penguin, 1995.

Schaar, R.M.A. van der. "Colonial Period of Indonesia." Indonesia-Investments, n.d. https://www.indonesia-investments.com/culture/politics/colonialhistory/item178.

Sofi, Muhammad Jauhari. "Politics of Female Identity in Traditional Java through the Prism of Pramoedya A. Toer's Gadis Pantai." Jurnal Walisongo 26, no. 2 (2018): 345-64. https://doi.org/http://dx.doi.org/10.21580/ws.26.2.3181.

Taqwiem, Ahsani. "Perempuan dalam Novel Bumi Manusia Karya Pramoedya Ananta Toer." Jurnal Tarbiyah 7, no. 2 (2018): 133-43. https://doi.org/10.18592/ tarbiyah.v7i2.2217.

Taylor, Jean Gelman. "Kartini in her historical context." Journal of the Humanities and Social Sciences of Southeast Asia 145, no. 2 (1989): 295-307. https://doi.org/ 10.1163/22134379-90003256.

Toer, Pramoedya A. This Earth of Mankind (transl. by Max Lane). New York: Penguin, 1990.

Walby, Sylvia. Theorizing Patriarchy. Oxford, UK \& Cambridge, USA: Blackwell Publisher Ltd., 1990. 